\title{
Komputerowy system do badań właściwości statycznych i dynamicznych źródeł energii elektrycznej do spawania łukowego
}

\author{
Computer system to static and dynamic properties \\ of power sources for arc welding testing
}

\section{Streszczenie}

Od kilku lat w Zakładzie Inżynierii Spajania Politechniki Warszawskiej prowadzone są prace badawczo-konstrukcyjne nad opracowaniem i wdrożeniem do praktyki systemu pomiarowego do badań właściwości statycznych i dynamicznych urządzeń zasilania łuku spawalniczego. Pierwsze wersje tego systemu były omawiane fragmentarycznie w publikowanych wcześniej opracowaniach. Najnowsza jego wersja, będąca połączeniem wirtualnego przyrządu pomiarowego ze sterowanym obciążeniem rezystancyjnym, jest przedmiotem tego artykułu. Omówiono w nim najważniejsze założenia konstrukcyjne oraz praktyczną realizację unikatowego systemu pomiarowego.

\section{Abstract}

During last few years in Welding Engineering Division of Warsaw University of Technology some research and design activities concerned on construction and implementation to practice a computer system for measuring static and dynamic properties of power supplies for arc welding have been carried on. Previous wersion of such system have been already described in former publicatins. The newest one being a combination of wirtual measuring device and controlled output resistance load module is described here. Basic design assumptions as well as the practical implementation of such innowative measuting system is described.

\section{Wstęp}

Ostatnie lata przyniosły ogromny postęp w konstrukcji urządzeń spawalniczych, szczególnie źródeł energii elektrycznej do spawania łukowego. Produkowane obecnie urządzenia, oparte na technice inwertorowej, są mniejsze i lżejsze, dają możliwość pełnej, bezstopniowej regulacji wielu parametrów energetycznych spawania oraz sterowania synergicznego. Dzięki możliwości niemal swobodnego kształtowania

Dr inż. Paweł Cegielski, dr hab. inż., Andrzej Kolasa, prof. PW, mgr. inż. Krzysztof Skrzyniecki, dr inż. Paweł Kołodziejczak - Politechnika Warszawska. czasowych przebiegów prądu i napięcia zasilających łuk spawalniczy, wprowadzane są m.in. nowe odmiany spawania MIG/MAG, oferujące nieznane wcześniej możliwości technologiczne, jakościowe czy związane z wymaganą wydajnością.

Procesy zachodzące $w$ łuku elektrycznym, szczególnie przy zastosowaniu nowoczesnych odmian metod spawania i stosowanych do ich realizacji urządzeń, nie są dokładnie poznane. W literaturze jest stosunkowo niewiele publikacji dotyczących budowy i właściwości technologicznych współczesnych urządzeń spawalniczych, a zastosowane rozwiązania konstrukcyjne i prowadzące do nich badania nie są, z oczywistych powodów, ujawniane przez producentów. Dlatego też, dla lepszego poznania zarówno procesów fizycznych zachodzących w łuku, jak i doskonalenia konstrukcji 
urządzeń w celu poprawy ich właściwości technologicznych, niezbędne jest opracowanie odpowiednich metod badawczych. Tradycyjne metody badań oraz oceny właściwości urządzeń o konwencjonalnych rozwiązaniach konstrukcyjnych, opartych na zewnętrznych charakterystykach statycznych, wyznaczeniu współczynnika Carerra [1], czy ocenie charakterystyk dynamicznych [5], zastosowane do urządzeń o nowoczesnych konstrukcjach, wykazują zazwyczaj ich dobre właściwości spawalnicze [15]. Jednak często nie znajduje to potwierdzenia w jakości spoiny. Przyczyna tkwi zapewne w niedoskonałości metod badawczych oraz złożoności konstrukcji urządzeń (ich charakterystyki statyczne i parametry dynamiczne mogą być dowolnie definiowane, a częstotliwość i sposób przechodzenia kropli są sterowane przez nadrzędne programy sterujące). Pojawia się zatem potrzeba znalezienia nowych i/lub odpowiedniego dostosowania dotychczasowych metod badań i przyjęcia odpowiadających im kryteriów oceny.

Celem prac podjętych w Zakładzie Inżynierii Spajania Politechniki Warszawskiej (ZIS PW) jest zbadania zależności pomiędzy procesami a zjawiskami fizycznymi zachodzącymi w łuku spawalniczym, a parametrami elektrycznymi obwodu łuk-źródło zasilania. Jednym z pierwszych etapów było stworzenie odpowiedniej bazy pomiarowej, w tym modernizacja opracowanego w ZIS PW i dotychczas eksploatowanego, nowatorskiego, komputerowego systemu do badań statycznych i dynamicznych spawalniczych źródeł energii

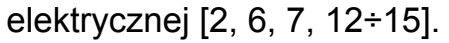

Przedstawione wyniki prac badawczych i konstrukcyjnych otrzymano w ramach pracy naukowej finansowanej ze środków budżetowych na naukę w latach $2010 \div 2013$ jako projekt badawczy [10].

\section{Założenia dla systemu pomiarowego}

Wiele zjawisk fizycznych zachodzących podczas spawania jest zależnych od charakteru prądu przepływającego przez łuk. Generowana w jego wyniku energia cieplna wywołuje procesy, których skutkiem jest topienie materiału, jego transport do spoiny, itp. To z kolei wpływa na zmianę parametrów elektrycznych obwodu łuk - urządzenie spawalnicze. Oczywiście, na zmiany rejestrowanych przebiegów (prądu spawania i napięcia łuku) mają wpływ zarówno źródło energii, jak i procesy zachodzące w łuku. Co jednak najważniejsze - zawierają w sobie informacje o procesach i przebiegu spawania.

Podstawowym elementem konstrukcyjnym spawalniczego zasilacza inwertorowego jest falownik (układ przełączający). Podawane na jego wejście napięcie stałe przekształcane jest w procesie kluczowania na napięcie przemienne o częstotliwości powyżej $20 \mathrm{kHz}$. Falowniki budowane są zazwyczaj na bazie

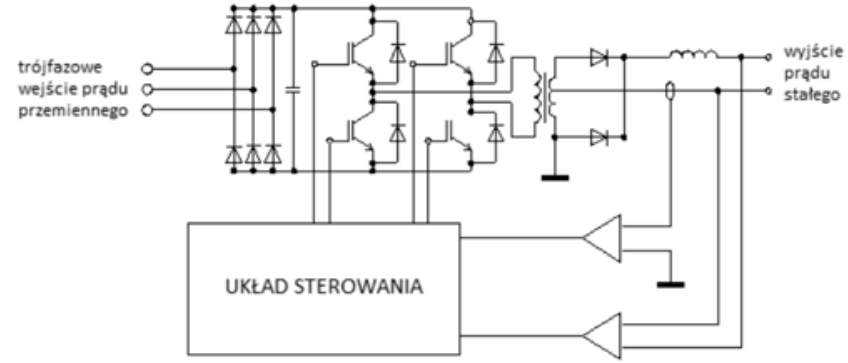

Rys. 1. Schemat zasilacza inwertorowego opartego na tranzystorach IGBT o małych stratach przełączania i szybkich prostownikach wyjściowych [17]

Fig. 1. The diagram of inverter arc power supply based on low switching losses IGBT transistors and fast output rectifiers [17]

tranzystorów mocy IGBT (rys. 1) [3, 9]. Sam falownik może być skonstruowany w oparciu o pełnomostkowy obwód czterech par tranzystor-dioda albo półmostkowy układ dwóch tranzystorów i dwóch diod, co upraszcza sterowanie, lecz pogarsza sprawność. Prąd wyjściowy źródła inwertorowego jest zależny od wymagań konkretnego procesu spawania, np. uzyskanie sterowanej charakterystyki prądu spawania (np. jego pulsacji) może wymagać zastosowania drugiego falownika.

Współczesne urządzenia inwertorowe wykorzystują duże częstotliwości przełączeń elementów półprzewodnikowych (nawet powyżej 100 kHz) w celu generowania energii o zadanych przebiegach. Stany nieustalone podczas takich przełączeń zależą od charakterystyk użytych elementów, ich konfiguracji, a także od charakterystyki obciążenia. Są one przedmiotem badań w elektrotechnice i energetyce, gdyż każde przełączenie odmienne od idealnego jest źródłem strat energii. W prowadzonych w ZIS PW badaniach wykorzystane zostaną jako nośnik informacji o procesach zachodzących podczas spawania. Z tego względu konieczne będzie opracowanie metod identyfikacji i rozgraniczenia reakcji urządzenia od reakcji łuku spawalniczego.

Do praktycznej realizacji tak sformułowanej metody badawczej niezbędny jest precyzyjny pomiar chwilowych zmian prądu spawania i napięcia łuku, ich rejestracja, a następnie odpowiednia obróbka zgromadzonych danych. Dotychczasowe doświadczenia pokazały, że nie wystarcza rejestracja milisekundowego przebiegu „zamrożonego” na ekranie oscyloskopu - wartościowe rejestracje muszą obejmować nie mniej niż kilkusekundowe przebiegi, o jak najwyższej jakości określonej m.in. pasmem przenoszenia przetworników pomiarowych, częstotliwością i rozdzielczością próbkowania. W dalszej kolejności konieczna jest odpowiednia obróbka tak dużej ilości danych. Przykładowo, jednosekundowa rejestracja prądu i napięcia, odbywająca się przy częstotliwości próbkowania $10 \mathrm{MHz}$ i rozdzielczości 12 bitów, powoduje zgromadzenie 400 MB informacji.

Kolejnym utrudnieniem są specyficzne zakłócenia pochodzące od cyklicznych przełączeń falownika. W spawalniczych źródłach zasilających częstotliwość 


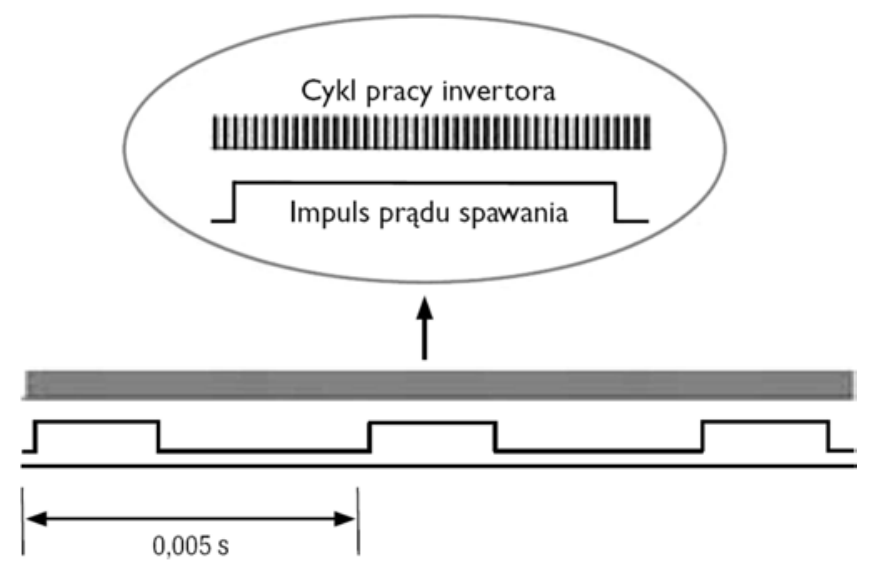

Rys. 2. Porównanie czasu trwania impulsu prądu spawania MIG Puls z okresem przełączania inwertora [4]

Fig. 2. The comparison of current pulse during MIG welding and inverter switching pulse duration [4]

przełączania, z jaką kluczowane są elementy przełączające inwertora, jest zawsze dużo wyższa od częstotliwości sterowanych (np. prądu pulsującego) lub samoistnych (np. procesu zwarć kroplami ciekłego metalu) zjawisk zachodzących w łuku. Na rysunku 2 przedstawiono typowy przypadek spawania prądem pulsującym MIG/MAG, gdzie czas trwania impulsu wynosi ok. $1 \mathrm{~ms}$, a częstotliwość pulsacji prądu spawania zawiera się w zakresie $100 \div 200 \mathrm{~Hz}$ [4]. Jak łatwo zauważyć, na jeden impuls prądu spawania przypada kilkadziesiąt impulsów generowanych przez inwertor, mimo że w prezentowanym na rysunku 2 przypadku zastosowano stosunkowo niewielką częstotliwość pracy inwertora, ok. $20 \mathrm{kHz}$. Oznacza to, że okres impulsu prądu spawania jest na tyle długi, aby było wystarczająco dużo czasu na reakcję i ewentualne korekty.

Tętnienia widoczne na krzywych prądu i napięcia spawania pokazane na oscylogramie, odpowiadają impulsom prądu wytwarzanym przez inwertor (rys. 3). Jednocześnie widać, że napięcie rośnie dość szybko, natomiast prąd podąża za nim znacznie wolniej. Powodem takiego stanu jest indukcyjność kabli na stanowisku spawania, nawet o długości poniżej $10 \mathrm{~m}$. Przeprowadzone testy dowodzą, że prędkość zmian prądu jest ograniczona przede wszystkim indukcyjnością kabli, a w znacznie mniejszym stopniu czasem reakcji źródła lub częstotliwością przełączania inwertora [4].

Obecność tętnień pochodzących od kluczowania tranzystorów badanego zasilacza może być źródłem nieporozumień, a ich wyodrębnienie wymaga specjalnych zabiegów. Zbyt mała częstotliwość próbkowania aparatury mierzacej powodować będzie istotne przekłamania, np. w postaci oscylogramów niezgodnych z rzeczywistym przebiegiem zjawisk zachodzących w łuku spawalniczym (rys. 4a). Skutkiem braku odpowiedniej aparatury, w starszych publikacjach pojawiały się błędne analizy tak zniekształconych przebiegów. Zabopiec temu może odpowiednie nadpróbkowanie (pomiar i rejestracja ze znacznie

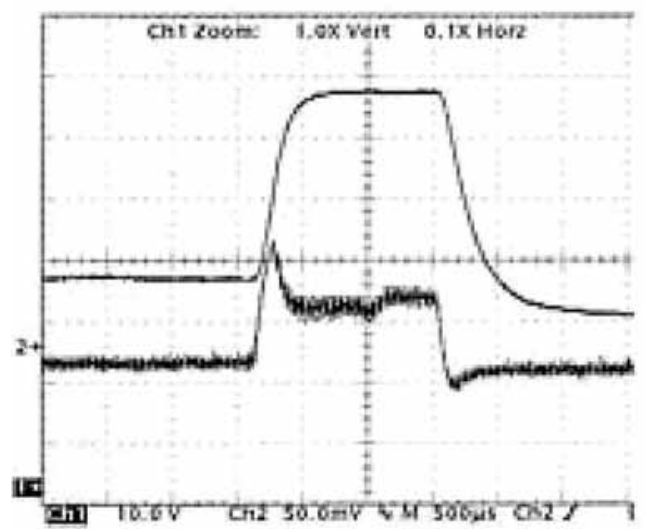

Rys. 3. Przebiegi prądu i napięcia podczas spawania MIG Puls drutem AIMg5 o średnicy 1,2 mm. Od góry: przebieg impulsów prądu (100 A/dz) i przebieg napięcia łuku (10 V/dz) [4]

Fig. 3. Current (up) and voltage (down) waveforms during MIG Pulse welding with AIMg5 electrode wire of dia. 1,2 mm. Welding current $100 \mathrm{amps} / \mathrm{div}$. and voltage 10 volt/div [4]

wyższą częstotliwością niż kluczowanie inwertora), a następnie filtracja sygnału (rys. $4 b$ ).

W prowadzonych w ZIS PW badaniach sprawdzona będzie filtracja sprzętowa (za pośrednictwem elektronicznych filtrów dolnoprzepustowych), która w odróżnieniu od programowej, poprzedza proces pomiaru. $Z$ uwagi na zakładaną rejestrację wielosekundowych przebiegów, uzyskanie pozytywnego efektu przyczyni się do znacznie mniejszej objętości rejestrowanych

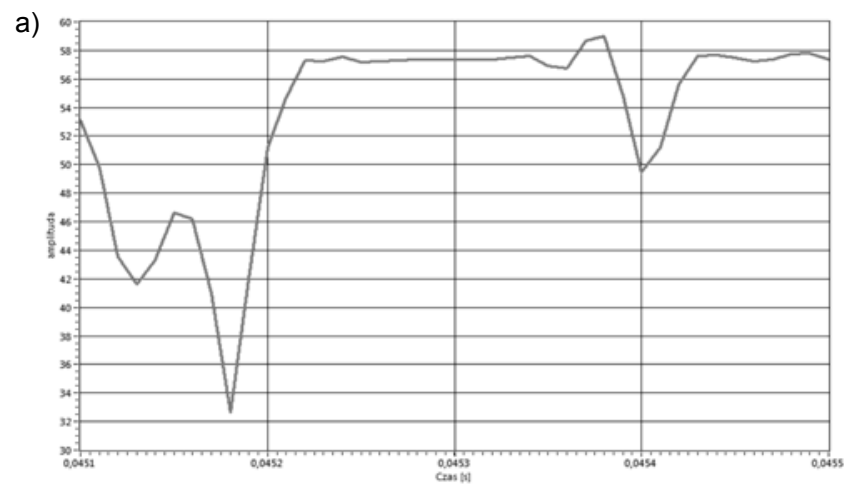

b)

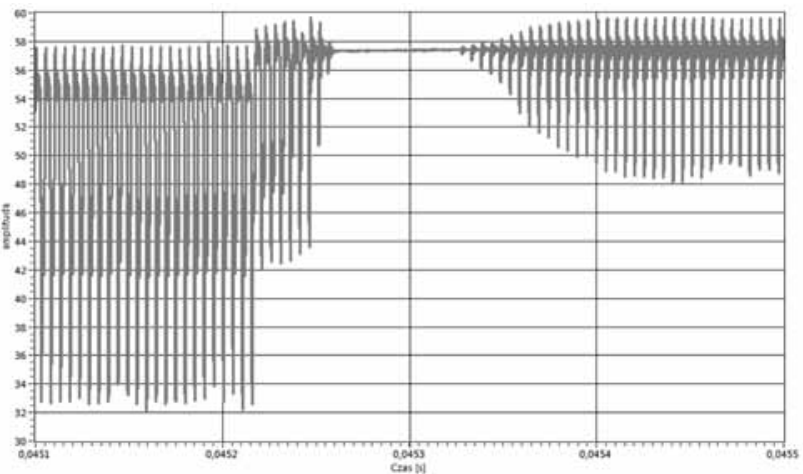

Rys. 4. Porównanie takiego samego przebiegu prądu spawania zarejestrowanego przy: a) niedostatecznej (100 kHz), b) wystarczającej $(10 \mathrm{MHz})$ częstotliwości próbkowania

Fig. 4. The comparison of welding current waveforms recorded with not adequte $(100 \mathrm{kHz})$ and adequate $(10 \mathrm{MHz})$ sampling frequency 
danych (można będzie bowiem znacznie zmniejszać częstotliwość próbkowania).

Założono także, że dzięki szczegółowej rejestracji parametrów spawania możliwe będzie, w przyszłości, wydzielenie składowych sygnałów elektrycznych determinowanych zewnętrznym zakłóceniem procesu spawania, powodującym wadliwość spoiny, i sygnalizacja tego stanu w czasie rzeczywistym procesu. Pociągnie to za sobą kolejny problem - konieczność ciągłej analizy, w czasie rzeczywistym pomiaru, bardzo dużej ilości danych.

Dla osiągnięcia postawionych celów zbudowana została nowa, innowacyjna wersja urządzenia badawczego, zapewniającego kompleksowe wyposażenie i oprogramowanie do pomiaru, rejestracji oraz bieżącej (w czasie rzeczywistym) i późniejszej (po zarejestrowaniu) analizy danych. Same pomiary, tak jak w dotychczasowych badaniach, będą się mogły odbywać zarówno w czasie spawania, jak i w warunkach symulowanego obciążenia badanego zasilacza spawalniczego wbudowanym, sterowanym obciążeniem rezystancyjnym. Możliwe będzie przy tym pozyskiwanie „konwencjonalnych" charakterystyk statycznych, jak oraz dynamicznych, przy zaprogramowanym, zmiennym obciążeniu rezystancyjnym o zadanej charakterystyce, obejmującym różnorodne przebiegi, skoki jednostkowe i całkowite zwarcie. Tego typu badania ze sterowanym, szybkozmiennym obciążeniem rezystancyjnym stanowią oryginalny wkład autorów do badań spawalniczych źródeł energii elektrycznej, z powodzeniem wykorzystywane w odniesieniu do różnorodnych źródeł do spawania łukowego $[2,6,7,12 \div 15]$.

\section{Koncepcja wirtualnego przyrządu pomiarowego}

Nowoczesne, autonomiczne przyrządy pomiarowe dają możliwość prowadzenia wszechstronnych, skomplikowanych i bardzo dokładnych pomiarów. Z równym powodzeniem mogą wejść w skład prostego, często doraźnie zmontowanego toru pomiarowego (rozumianego jako zbiór elementów całkowicie niezależnych), jak i wysoce zautomatyzowanego systemu, objętego wspólnym sterowaniem i rejestracją wyników. Najbardziej rozbudowane, skomputeryzowane przyrządy autonomiczne zwane są niekiedy inteligentnymi. Jednak od chwili powszechnego wprowadzenia komputerów osobistych powielanie standardowych bloków sterowania komputerowego wewnątrz obudowy każdego inteligentnego przyrządu stało się, zdaniem wielu autorów wysoce nieracjonalne $[11,16]$. Coraz częstszą alternatywą stają się przyrządy wirtualne.

Przyrząd wirtualny definiowany jest jako rodzaj przyrządu pomiarowego powstałego w wyniku sprzężenia sprzętu pomiarowego (jak karty pomiarowo-sterujące czy czujniki pomiarowe) z komputerem osobistym ogólnego przeznaczenia i oprogramowaniem, które może umożliwiać pracę systemu na zasadach

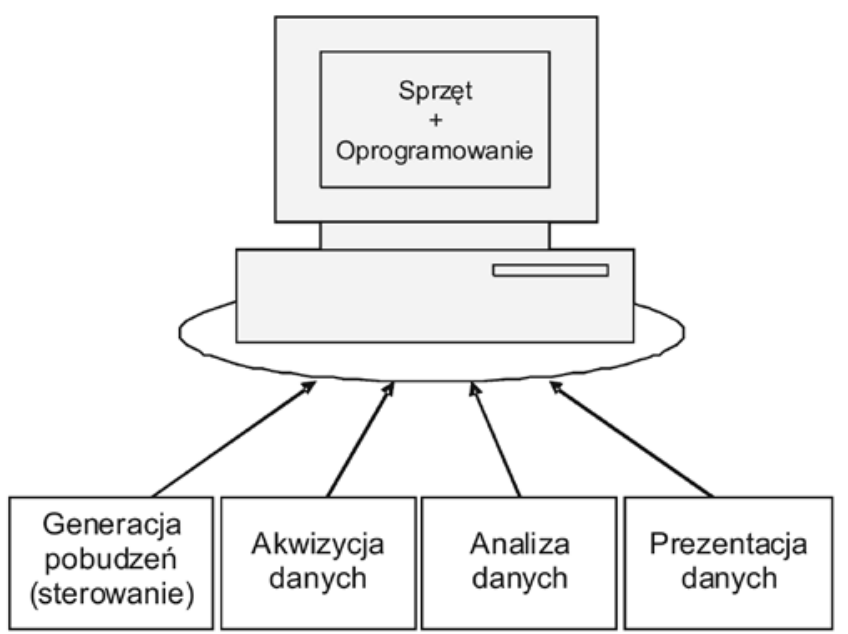

Rys. 5. Idea wirtualnego przyrządu pomiarowego [11]

Fig. 5. The principle of wirtual measuring device [11]

takich, jak przy obsłudze tradycyjnego przyrządu pomiarowego [11]. Aby stworzyć tego typu system trzeba wyposażyć komputer osobisty np. w kartę zbierania danych (DAQ - Data Acquisition Card), napisać odpowiadające własnym potrzebom oprogramowanie użytkowe i realizować zamierzone funkcje pomiarowe (rys. 5).

Do najważniejszych narzędzi programistycznych wspomagających projektowanie przyrządów wirtualnych zalicza się pracujący w środowisku graficznym pakiet LabView firmy National Instruments [8]. Tworzenie aplikacji pomiarowej przebiega dwutorowo - jednocześnie powstaje graficzna prezentacja przepływu mierzonych sygnałów obrazująca działanie aplikacji, użyte funkcje i procedury oraz przyjazny dla użytkownika interfejs operatorski (rys. 6).

Dotychczasowe doświadczenia z wersją 7.1 pakietu w pełni potwierdziły jego przydatność, a zastosowana w zmodernizowanym systemie pomiarowym najnowsza wersja LabVIEW 2011 oferuje nowe możliwości $[2,13]$. Należą do nich m.in. jeszcze większe możliwości integracji sprzętu z oprogramowaniem, nowe biblioteki przekształceń i procedur, większa szybkość tworzenia aplikacji, w tym jej testowania i modyfikacji.
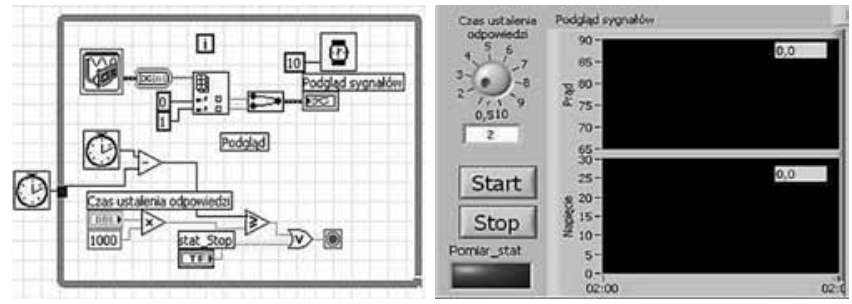

Rys. 6. Przykład kodu sterującego pomiarem i interfejsu użytkownika, uzyskane w LabView [8]

Fig. 6. An example of measurement and user interface controll code of LabView software [8] 
Na szczególną uwagę zasługują jednak dwa nowe, specjalizujące dodatki:

- NI LabVIEW System Identification Toolkit, który umożliwia m.in.: zaawansowaną obsługę kart pomiarowych (generowanie sygnałów sterujących), akwizycję danych i ich przetwarzanie wg zaprogramowanych algorytmów oraz wizualizację wyników;

- DIAdem NI, który jest odrębnym narzędziem służącym do szybkiej lokalizacji, wizualizacji i analizy danych pomiarowych zebranych podczas ich pozyskiwania i/lub wytworzonych podczas symulacji. Aplikacja została zaprojektowana na potrzeby zadań wymagających szybkiego dostępu, obróbki i raportów w odniesieniu do bardzo dużej ilości danych, również występujących w wielu niestandardowych formatach.

Obok narzędzi programistycznych, niezbędnym wyposażeniem jest osprzęt tworzący kompletny tor pomiarowy: instalowane w nadrzędnym komputerze PC karty pomiarowo-sterujące i oscyloskopowe oraz przetworniki (czujniki) mierzonych wielkości. W omawianym przypadku wykorzystano sprawdzone już poprzednio elementy, w tym m.in.:

- przetwornik prądu VACUMSCHMELZE T60404N4644X055, $50 \mathrm{kHz}, 500 \mathrm{~A}$;

- szerokopasmowy przetwornik napięcia LEM CV 3-200, 300 kHz, +/- 200 V DC;

- karta pomiarowo-sterująca $\mathrm{NI} \mathrm{PCI} \mathrm{-} \mathrm{6251,} 16$ I/O analogowych, 24 I/O cyfrowych, 6 kanałów DMA 2 wewnętrzne timery: $20 \mathrm{MHz}$ i $80 \mathrm{MHz}$, częstotliwość próbkowania 1,25 ms/s na kanał (National Instruments);

- specjalistyczna karta oscyloskopowa PCI-DAS 4020/12, dwa kanały po $20 \mathrm{MS} / \mathrm{s}$, rozdzielczość 12 bitów (Measurement Computing Corporation);

- specjalizowana karta dźwiękowa MAYA 44MK2 (Audiotrak);

- mikrofon pojemnościowy (fantomowy) SY91 (Sound Import, Chorzów).

Karta pomiarowo-sterująca, ze względu na ograniczone pasmo pomiarowe, wykorzystywana jest przede wszystkim do sterowania pomiarem, w tym omówionym w artykule obciążeniem rezystancyjnym, oraz do prostszych pomiarów, np. charakterystyk statycznych. Dodatkowa, specjalizowana karta oscyloskopowa ma służyć do pomiaru szerokopasmowego podczas obciążeń dynamicznych badanego zasilacza, w tym podczas spawania. W tym przypadku, z uwagi na ogromną ilość przekazywanych danych, istotnym ograniczeniem staje się czas rejestracji, który w praktyce nie przekracza kilku sekund.

\section{Realizacja praktyczna nowego systemu pomiarowego}

Na rysunku 7 przedstawiono uproszczony schemat blokowy zbudowanego systemu pomiarowego. Stanowi on rodzaj wirtualnego przyrządu pomiarowego o strukturze otwartej, opartej na karcie akwizycji danych $D A Q$, integrującej tor pomiarowy i blokowy zbudowanego systemu pomiarowego.

W odróżnieniu od wcześniejszej, zwartej konstrukcji urządzenia, w całości umieszczonej wewnątrz stalowej obudowy, nowa przyjęła postać modułową - ramową (rack). Uzyskana w ten sposób swoboda aranżacji przestrzeni pozwoliła na optymalne rozmieszczenie poszczególnych elementów, zarówno pod względem termicznym, jak i wzajemnego zakłócania (rys. 8). W przyszłości możliwa będzie dowolna rozbudowa i modyfikacja systemu.

Nowatorskim składnikiem pierwotnie opracowanej aparatury pomiarowej jest blok mocy, na który składają się rezystory drutowe wraz z przełączającymi je kluczami tranzystorowymi IGBT. W ramach modyfikacji uproszczono sekwencje włączeń rezystancji, redukując ich liczbę z 65 do 22. Zastosowano najnowsze bloki tranzystorowe IGBT (CM800DU-12H, Mitsubishi), zdolne do realizacji stanu pełnego zwarcia badanego zasilacza pojedynczym kluczem (zamiast pierwotnie stosowanego „powolnego” stycznika elektromagnetycznego), a połączenia obwodu mocy

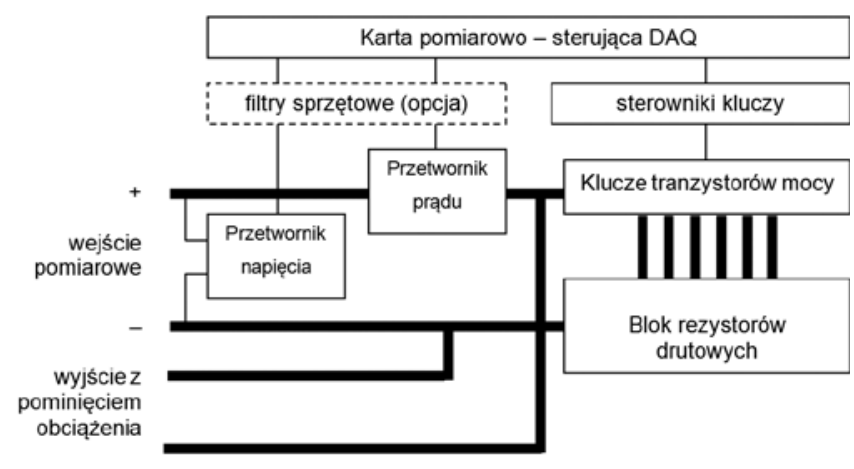

Rys. 7. Schemat blokowy zbudowanego systemu pomiarowego Fig. 7. The block diagram of the measuring system
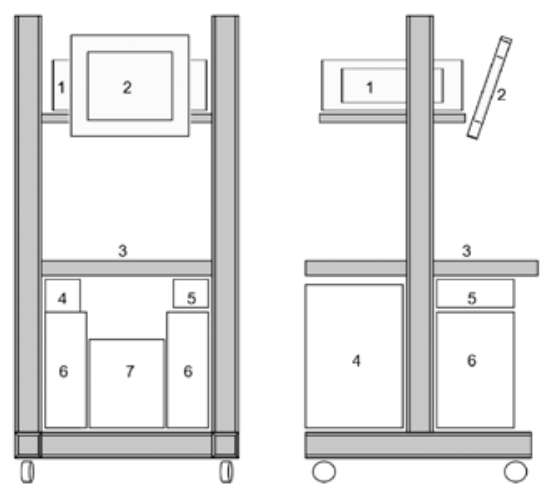

Rys. 8. Schemat rozmieszczenia elementów systemu pomiarowego: 1 - komputer pomiarowy, 2 - monitor, 3 - półka na dodatkowy komputer i izolacja termiczna, 4 - kaseta sterowników kluczy i zasilaczy, 5 - przetworniki i gniazda pomiarowe, 6 - dwa bloki kluczy IGBT, 7 - blok rezystorów drutowych

Fig. 8. The arrangement of the measuring system components: 1 - measuring computer, 2 - monitor, 3 - space for additional computer and thermal isolation, $4-$ controllers, switches and supplies module, 5 - converters and measuring sockets, 6 - two IGBT switching modules, 7 - wire resistors module 


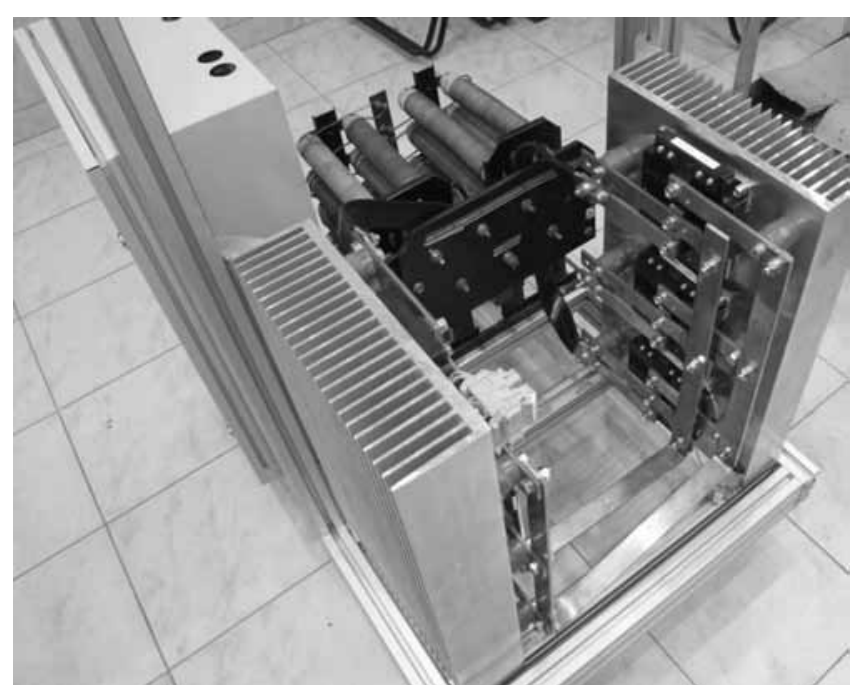

Rys. 9. Połączenia obwodu mocy, obejmującego bloki IGBT oraz rezystory drutowe

Fig. 9. The wiev of power circuit consisting of IGBT transistors and wire resistors

zrealizowano wyłącznie stosująć płaskowniki i elastyczne taśmy miedziane (rys. 9). Dzięki tym zabiegom znacznie wzrosły zakresy mierzonych parametrów, szybkość i przejrzystość układu oraz poziom bezpieczeństwa toru obciążającego.

Poniżej przedstawiono najważniejsze parametry uzyskane po modernizacji (w nawiasach wartości przed zmianami):

- maksymalny prąd wejściowy: ciągły 800 (400) A DC, chwilowy 1500 (800) A DC,

- maksymalne napięcie wejściowe: 400 (200) V DC,

- sterowana programowo (automatyczna) zmiana

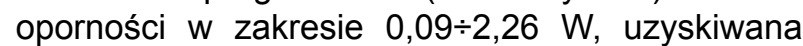
w 22 (65) krokach, obejmujących także stan jałowy - bez obciążenia i pełne zwarcie kluczem tranzystorowym (poprzednio stycznikiem elektromagnetycznym),

- maksymalna szybkość zmiany obciążenia do ok. $20 \mathrm{kHz}$, obejmująca także stan pełnego zwarcia (poprzednio stan pełnego zwarcia nie mógł być w pełni ujęty w szybkozmiennym cyklu obciążającym).

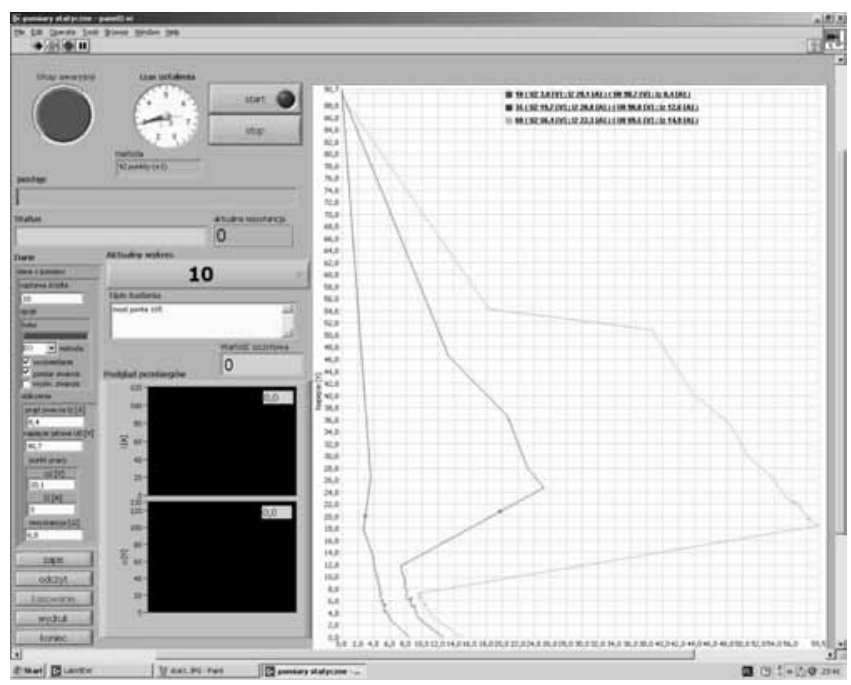

Rys. 10. Jeden z paneli sterujących - procedura pomiaru charakterystyk statycznych

Fig. 10. One of controll panel - the static output characteristic measurement procedure

Zrezygnowano także ze znanych z poprzedniej wersji fizycznych układów ręcznego sterowania obciążeniem i przyrządów wskaźnikowych (średnich wartości prądu spawania i napięcia łuku) oraz logiki sterującej i zabezpieczającej (zabezpieczenia termiczne, przed niedozwolonymi załączeniami obciążenia itp.), przenosząc je w całości do programu sterującego zrealizowanego w środowisku LabView. Usunięto w ten sposób źródła licznych zakłóceń (przez zminimalizowane liczby połączeń, obwodów, zasilaczy itp.) i ograniczeń funkcjonalnych - zamiast sztywnej logiki sterującej opartej na mikroprocesorze, wykorzystano dowolnie zmienna logikę zaprogramowaną w środowisku sterującym. Na rysunku 10 pokazano przykładowo jeden z wirtualnych paneli sterujących, działający w środowisku LabView. Ogólnie, aplikacja komputerowa w całości steruje obciążeniem rezystancyjnym, niezbędnym do wykonywania charakterystyk statycznych i symulowanych dynamicznych, a także odpowiada za pomiar i rejestrację parametrów oraz ich późniejszą analizę. Zagadnienia te będą przedmiotem dalszych analiz.

\section{Podsumowanie}

Przeprowadzone badania funkcjonalne zmodyfikowanej, innowacyjnej wersji systemu do badań spawalniczych źródeł energii z automatycznym sterowaniem, rejestracją i analizą wyników, wykazały jej wysoką jakość i funkcjonalność. Jednocześnie, prowadzonym badaniom towarzyszą ciągłe modyfikacje aplikacji sterujących oraz udoskonalanie układów elektronicznych. Umożliwiają one prowadzenie dalszych prac skoncentrowanych nad wyznaczeniem modeli lub tabeli zależności pomiędzy procesami zachodzącymi w łuku spawalniczym a przebiegami elektrycznymi w czasie spawania. Zależności te posłużą do pogłębienia wiedzy o procesie spawania, wyznaczenia nowych kryteriów oceny przydatności urządzeń spawalniczych, nowych metod diagnostyki spoin oraz ograniczenia energochłonności procesu spawania. 


\section{Literatura}

[1] Carrer A.: Dynamic behavior of DC arc welding generators for arc welding. IIW Doc. 11-31-58.

[2] Cegielski P., Kolasa A.: Komputerowy system do badań właściwości statycznych i dynamicznych spawalniczych źródeł energii elektrycznej. Prace Naukowe Politechniki Warszawskiej, Mechanika, z. 215, Warszawa 2006.

[3] Katalog firmy Mitsubishi: IGBT Modules. High Power switching use insulated type.

[4] Kemppi Pro News, Biuletyn informacyjny firmy Kemppi, $3 / 2004$.

[5] Kolasa A.: Właściwości dynamiczne źródeł energii elektrycznej do spawania łukowego oraz kryteria ich oceny. Prace $\mathrm{Na}$ ukowe Politechniki Warszawskiej, Mechanika, z. 135, Warszawa 1990.

[6] Kolasa A., Cegielski P., Węglowski M., Skrzyniecki K.: Technical performance of low power welding inverters. 4th International Conference APE'07, Warszawa 2007.

[7] Kolasa A., Cegielski P., Węglowski M., Skrzyniecki K.: Właściwości dynamiczne inwertorowych źródeł energii elektrycznej do spawania metodą MIG/MAG. Prace Naukowe Politechniki Warszawskiej, Mechanika, z. 229, Warszawa 2009.

[8] LabVIEW 2011 Express. User Manual, National instruments 2011.

[9] Nowak S., Barlik R.: Poradnik Inżyniera energoelektronika. WNT, Warszawa 1998.
[10] Projekt badawczy własny Ministra Nauki i Szkolnictwa Wyższego nr N N503 206339 pt. Badanie zależności pomiędzy zjawiskami zachodzącymi w łuku spawalniczym w różnych odmianach metody MAG a parametrami elektrycznymi układu łuk - urządzenie spawalnicze. Kierownik: prof. nzw. dr hab. inż. Andrzej Kolasa.

[11] Rak R.J.: Wirtualny przyrząd pomiarowy. Oficyna Wydawnicza Politechniki Warszawskiej, Warszawa 2003.

[12] Skrzyniecki K., Kolasa A., Cegielski P.: Badanie charakterystyk statycznych i dynamicznych układu źródło zasilania - łuk. Przegląd Spawalnictwa 6/2011.

[13] Skrzyniecki K., Krajewski A., Cegielski P., Hudycz M., Kolasa A.: Zastosowanie wirtualnych przyrządów pomiarowych do badania urządzeń i procesów spawalniczych. Prace Naukowe Politechniki Warszawskiej, Mechanika, z. 229, Warszawa 2009.

[14] Węglowski M., Kolasa A., Cegielski P.: Badania właściwości technologicznych spawalniczych zasilaczy inwertorowych. Przegląd Spawalnictwa 9-10/2006.

[15] Węglowski M., Kolasa A., Cegielski P.: Ocena stabilności procesu ręcznego spawania łukowego elektrodami otulonymi. Przegląd Spawalnictwa, 1/2006.

[16] Winiecki W.: Organizacja komputerowych systemów pomiarowych. Oficyna Wydawnicza Politechniki Warszawskiej, Warszawa 1997.

[17] www.dacpol.pl: Postęp w elektronicznych zasilaczach do spawarek. Artykuł branżowy, publikacja z 10.09.2004.

\section{Seminarium}

\section{Robotyzacja procesów spawalniczych}

W dniach $29.11 \div 01.12 .2011$ r. w Regionalnym Centrum Aplikacji ABB w Aleksandrowie Łódzkim odbyło się seminarium pt.: Robotyzacja procesów spawalniczych. Seminarium zorganizowała firma ABB wraz z partnerami: ESAB, Abicor-Binzel i Roboprojekt,

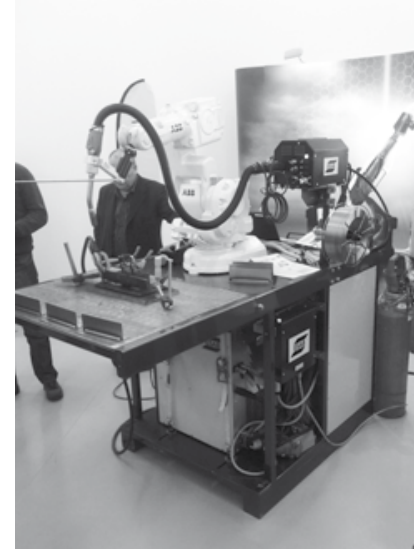

Zrobotyzowane stanowisko spawalnicze

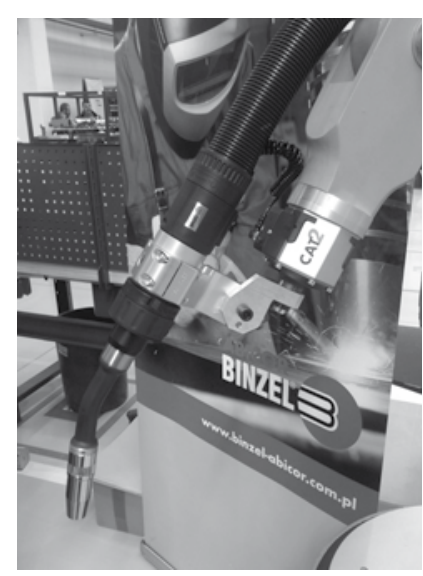

Uchwyt elektrodowy a nad wydarzeniem objął patronat Instytut Spawalnictwa w Gliwicach.

Podczas seminarium przedstawiono zrobotyzowane aplikacje wykonywane przy zastosowaniu robotów ABB oraz oprzyrządowania dostarczanego przez partnerów. Zaprezentowano nowe modele znanych i cenionych cel spawalniczych FlexArc wyposażonych w nadgarstek hollow wrist o nowoczesnej konstrukcji. Omówiono oprogramowanie aplikacyjne RobotWare ARC dedykowane do procesów spawalniczych i funkcjonalność oprogramowania RobotStudio z dodatkiem Arc Welding PowerPac. Istotnym elementem było połączenie prezentowanych informacji z pokazem praktycznym możliwości programowania i obsługi robotów, jak również innych aplikacji związanych z obróbką powierzchni. Obecność przedstawicieli firm partnerskich ABB umożliwiła zaznajomienie się z kluczowymi kryteriami doboru elementów wyposażenia stanowisk zrobotyzowanych, a także produktami dedykowanymi do robotyzacji procesów spawania.

W trakcie seminarium nie pominięto również ekonomicznych aspektów inwestycji w zrobotyzowane stanowiska spawalnicze, które przedstawił dr inż. Tomasza Pfeifer z IS w Gliwicach, omawiając także metody oceny efektywności wdrożeń stanowisk do spawania robotyzowanego. 